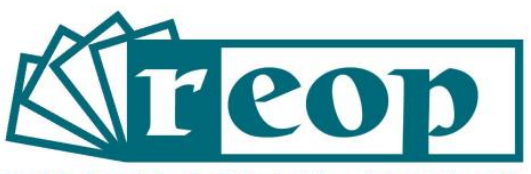

Revista Española de Orientación y Psicopedagogía

\title{
ROLE SALIENCE AND SATISFACTION IN WORKING ADULTS: A CONTRIBUTION TO THE INDIVIDUALS' WELL-BEING
}

\section{LA RELEVANCIA Y LA SATISFACCIÓN CON LOS ROLES VITALES EN LOS TRABAJADORES ADULTOS: UNA CONTRIBUCIÓN PARA EL BIENESTAR DE LOS INDIVIDUOS}

\author{
Rosário Lima ${ }^{1}$ \\ Universidad de Lisboa. Facultad de Psicología. Servicio a la Comunidad. Lisboa, Portugal \\ Pedro Gaspar \\ Universidad de Lisboa. Facultad de Psicología. Servicio a la Comunidad. Lisboa, Portugal
}

\section{RESUMEN}

Con base en un estudio sobre la relevancia de los roles con una muestra de adultos que solicitaron ayuda en el contexto de asesoramiento y gestión de carrera, se encontró una tendencia a dar más y más importancia a los roles que no sean los que generalmente los individuos tienden a gastar más de su tiempo y energía: el trabajo y la familia. Este estudio tiene como objetivo presentar más resultados que confirmen esta tendencia, en diferentes contextos organizacionales, y también la satisfacción obtenida con los roles de vida profesional, familiar y de ocio. Las muestras en estudio incluyeron adultos trabajadores, cuyos totales oscilaron entre 60 y 116 participantes, y los instrumentos utilizados fueron el Inventario de Saliencia de Actividades y la Escala de Satisfacción con los Roles Vitales. Los resultados corroboran la tendencia mencionada y revelan mayores niveles de satisfacción con otras actividades que la profesional, y correlaciones entre la relevancia de los roles y la satisfacción con los roles de vida. Por consiguiente, debe considerarse estratégico que las organizaciones implementen medidas destinadas a facilitar el equilibrio entre los diferentes roles desempeñados por sus trabajadores. Cabe destacar las intervenciones en asesoramiento y gestión de la carrera y el uso cada vez más frecuente del trabajo remoto. Se hacen algunas consideraciones sobre la importancia de ayudar los individuos a

${ }^{1}$ Correspondencia: Rosário Lima. Correo-e: rosariolimapt@gmail.com, web: https://www.psicologia.ulisboa.pt/ 
lidiar con sus niveles de satisfacción y bienestar en el actual mercado laboral competitivo, impredecible y desconocido.

Palabras clave: adultos trabajadores; asesoramiento y gestión de carrera; bienestar; medidas organizacionales; relevancia de los roles; satisfacción con los roles vitales.

\begin{abstract}
A study about role salience in the counselling and career management context with an adult sample revealed the tendency for the individuals to place more importance in other roles beyond those they tend to spend more time and energy with work and family. The aim of this research is to present more results that confirm this trend, in different organizational contexts, and the satisfaction with the occupational, family and leisure life roles. The study samples included working adults, ranging from 60 to 116 participants, and the instruments used were the Salience Inventory and the Life Roles Satisfaction Scale. The results corroborate the referred trend and reveal higher levels of satisfaction with other activities than with the occupational one, and correlations between role salience and satisfaction with the life roles. Therefore, it should be considered strategic by the organizations to implement policies aiming to facilitate the balance between the different roles played by their employees. Noteworthy are the interventions in counselling and career management and the increasingly frequent use of remote work. Some considerations are made on the importance of helping individuals to deal with their levels of satisfaction and well-being in the current competitive, unpredictable, and unknown labour market.
\end{abstract}

Key Words: adult workers; counselling and career management; organizational practices; role salience; satisfaction with life roles; well-being.

\title{
How to cite this article:
}

Lima, R. \& Gaspar, P. (2021). Role salience and satisfaction in working adults: a contribution to the individuals' well-being. Revista Española de Orientación y Psicopedagogía, 32(1), 28-40.

https://doi.org/10.5944/reop.vol.32.num.1.2021.30738

\section{Introduction}

The individual plays several positions, through his/ her lifetime - as a worker, as a boss, as a student, as a friend, or as a parent, and each of these positions can be understood as a role: a set of behaviours that are modelled by social expectations (Sverko et al., 2008). When formalized, these expectations become norms, involving punishments and rewards that encourage the expected behaviours. By complying with this norms and expectations, the individual is assuming a certain role, that can be defined as a pattern of certain behaviours, rights and duties expected to be present in every specific social situation, and to which the individual attaches importance, and obtains satisfaction (Sverko et al., 2008). 
Although every individual represents a range of interests, skills, and priorities, every single one of them behaves through a unique combination of characteristics (Cook, 1994), that is, through his/ her personal singularity. Therefore, to understand what gives meaning and structure to the individual's life represents a valid contribute to contemplate his/ her involvement in a variety of roles (Cook, 1994), including not only the worker role, but also others, such as the student, citizen, homemaker, and leisure ones (Super, 1990). The performance of the several life roles requires time and energy in carrying out the different activities in the different contexts the individuals are in, and experiencing these different scenarios contributes to the definition of lifestyle, and to the achievement of both personal and professional goals.

The role salience refers to the importance the individual assigns to the activities he/ she performs in the various domains of his/ her life (Super, 1990), and it can be determined based on the Role Importance Model (Kidd \& Knasel, 1979). This model is structured on three levels, and the importance of a role can manifest through attitudes and emotions, behaviour, and knowledge. The first level includes commitment (referring to the emotional commitment of the individual with a role), participation (actual expenditure of time and energy on a role), and knowledge (acquisition of knowledge through direct or indirect experience of a role) (Nevill \& Super, 1986). On the second level, there are three components: involvement, interest, and engagement; and on the third, there is one component - importance -, which derives from the combination of the previous components from the previous levels. Although the literature in the last decades suggests that the worker and homemaker roles keep being the most salient in the adult workers' life (Super, 1980; Sverko \& Super, 1995; Lassance \& Sarriera, 2009; Kuykendall et al., 2020), nowadays individuals are spending more of their time in other activities outside these contexts, which contributes to their well-being and overall satisfaction with life. In the present study, the set of these activities are designated as leisure activities, referring to the fulfilment of time lapses with activities the individuals associate with moments of pleasure and well-being, lived through both individual and collective experiences (Bloom et al., 2018; Pöllänen \& Voutilainen, 2018).

But if it is important to consider the role salience, equally relevant is the satisfaction that is obtained by carrying out the activities associated with them, since the more salient a role is for the individual, the greater is the tendency for he/ she to devote more time, and to put more emotion into it (Stryker \& Serpe, 1994). The literature has shown that the increase of occupational satisfaction leads to the increase of occupational performance levels (e.g., Hoboubi et al., 2017; França et al., 2020), which highlights the importance for the organizations to have workers that are satisfied with their job, but also with other activities that give them pleasure, and that they need to balance with the worker role. It is therefore a valid contribution to the organizations the implementation of work-life balance practices and, consequently, the promotion and facilitation of the equilibrium between the various areas of life (Hamid, 2012). In this regard, the Spillover Theory suggests that the individual can transfer his/ her emotional state (either positive or negative) from a role to another, so the dissatisfaction in one role may contribute to the dissatisfaction in another, and vice versa (Wang et al., 2020). That said, positive experiences in a specific role can also lead to satisfaction in the various life roles, resulting in the increase of satisfaction with life in general (Stoilkovska et al., 2017), or with the subjective well-being, conceptualized as the individual's cognitive and affective evaluation about his/ her life or specifically about any life domain (Kuykendall et al., 2020) - that is, the evaluation, by comparison, that the individual makes of what he/ she has in his/ her life, with what he/ she idealizes as the ideal standard of life (Diener, 1984; Navarro et al., 2020). For instance, there is much evidence that shows that work and family are two areas which can affect each other (Work-Life-Interference), so the worker role can boost the positive effects in the homemaker role, specifically affecting the level of satisfaction with the family (Harpaz \& Fu, 2002).

An investigation by Stubbe et al. (2005) found out that the levels of satisfaction with the specific domains of the individual's life (e.g., occupational satisfaction) are an important information for the explanation of his/ her levels of satisfaction with his/ her life in general (Pavot \& Diener, 2008), once there is a relation between the judgment of a specific aspect of an individual's life with the levels of satisfaction with life in general. Though, roles influence each other, directly or 
indirectly, and can be carried out simultaneously, resulting in higher or lower levels of satisfaction. When there is no possibility for the individual to find an efficient and effective balance between the different roles carried out, he/ she tends to experience conflict situations. Once this phenomenon occurs, physical and mental health are affected, leading to higher levels of stress, anxiety, burnout, among other consequences (Allen et al., 2000), leading to lower levels of satisfaction with life in general. To better overcome the experience of conflict situations, it is important for individuals to be able to find and set priorities in which they perceive that work and non-work roles are balanceable, and to stimulate their growth according to the priorities imposed in their own lives, while experiencing work-life-balance (Kalliath \& Brough, 2008). This positive work-life balance can result in satisfaction and well-being for the individuals (Lima et al., 2014).

Although satisfaction with life in general can be a good indicator of the subjective well-being, it can vary depending on the roles the individuals perform (Lima \& Janeiro, 2012). These roles represent the time spent by individuals in the various activities they carry out, influencing one another, directly or indirectly, being performed simultaneously or in complementarity, and often resulting in different levels of satisfaction. Thus, it is especially relevant to assess satisfaction with each of the different life roles, contributing to the positive assessment of satisfaction with life in general and well-being of individuals.

Job satisfaction, or occupational satisfaction, can be defined as a positive emotional state that results from the positive evaluation of work and of the experiences it provides (Locke, 1976). The worker role, as a set of activities that the individual is expected to do, implicitly or explicitly, while at work (Jian \& Dalisay, 2018), can be understood as a structural element in his/ her life, giving it meaning, once it helps establishing a routine, providing him/ her a social life and a source of interest (Super, 1980).

Referring to the family satisfaction, it can be defined as being a notion of the family functioning, based on both cognitive and emotional individual's evaluation, and which leads to a feeling of pleasure and well-being (Olson, 2000; Schnettler et al., 2018). Thus, at cause are the satisfaction levels of the individual with his/ her family structure. This is defined as the social group characterized by the intimate and intergenerational relationships (Petzold, 1996), including, for instance, the parent-son/ daughter, or the siblings' relationship. These are subjacent to the family structure, and depend on various factors (e.g., marital satisfaction, existence of children, lack of family support). These factors should not only be considered in the individual's daily activities in his/ her family context, but also in the less frequent activities, such as family vacations or family leisure activities.

As to the leisure role, it can be defined as the set of activities, structured, that give response to the individual's needs, whether physical or "spiritual" (e.g., practical, intellectual, artistic, and social), considering the society's economic, social, political, and cultural possibilities (Nunes \& Hutz, 2014; Creighton-Smith et al., 2017). The importance given to this role by the individual, as well as the satisfaction obtained with the diversity of activities that this context provides, has been increasing over time. This may be the result, among other things, of the decrease in working weeks, the availability of leisure resources, and the increase in longevity, wages, and healthrelated awareness, which leads individuals to seek activities that provide a healthier and a wellbeing focused routine (Lima et al., 2014). The leisure role represents the time the individual dedicates to himself/ herself, through the performance of activities that provide the development of other skills or competences and other areas of interest, as well as pleasure, satisfaction, and wellbeing, which are not related to professional, familiar, and social obligations (Dumazedier, 2000).

Given the constant challenges and changes the individuals are currently facing, the work-life balance affects their well-being levels, their attitudes, and their behaviours, both in their life in general, and in the working environment. Assessing the satisfaction with the occupational, family and leisure life roles includes, generically, assessing the roles that cover the various kinds of activities that individuals engage in throughout the day by day at the different stages of their lives. So, as satisfaction with life can vary according to the different contexts or life roles, it is important 
to help individuals to deal not only with their role salience but also with their levels of satisfaction and well-being in the current competitive, unpredictable, and unknown labour market.

\section{Method}

\section{Sample}

The study consists of eight samples, whose dimensions vary between 60 and 116 participants. The participants are adult workers of both sexes and different age ranges, and the amplitude varies between 19 and 72 years old. Noteworthy is the fact that the various subsamples are contextspecific and quite differentiated (e.g., student-workers, area of Law, industry sector).

\section{Instruments}

The instruments used were the Salience Inventory (SI) ( $3^{\text {rd }}$ Edition) (Nevill \& Super, 1986) and Satisfaction with Life Roles Scale (SLRS) (Janeiro \& Lima, 2013; Ortuño et al., 2016).

$\mathrm{SI}$ is a psychological assessment instrument, which was developed under the context of the Work Importance Study (WIS), that aims to evaluate the salience of five roles (study, worker, citizen, homemaker and leisure) in three different dimensions: Participation (use of time and effort in the performance of the different roles), Commitment (the affective component, concerning the emotional attachment to the different roles), and Knowledge (the cognitive component, involving the information and comprehension of the different roles). The basis of methodologies used in the development of the SI had as a concern the instrument's validity and internal consistency, and the scales' independency from one another (Nevill \& Super, 1986). Only the Participation and Commitment scales were used. When administrating the SI, participants are asked to position themselves on a four-point scale (never or rarely; sometimes; often; almost always or always) in relation to the 100 items of the two scales used (Participation and Commitment). The inventory's items describe activities, that in the Participation scale are preceded by the sentence "What do you do or have done recently in... the following activities...", and in the Commitment scale are preceded by "What do you feel about... the following activities..." (Lima, 1998). In recent studies (e.g., Evangelista, 2017; Queirós, 2017; Dias, 2018), the SI has shown high values of internal consistency - Cronbach Alpha values varying between 0,74 and 0,94. These precision coefficients confirm the internal consistency values obtained when assessing the instrument to the Portuguese version (Ferreira-Marques \& Miranda, 1995), having the values in all the scales reached above 0,80 .

The SLRS was developed to assess the individuals' satisfaction with their performance in three life roles: Occupational, Family and Leisure. Consisting of 11 items, aggregated into three factors related to satisfaction with the three life roles, answers are given according to the level of agreement with each of the sentences, using a five-point Likert scale (from "I totally disagree" to "I totally agree"). To contribute to the validation of the scale, factorial analyses have been performed confirming the existence of the three dimensions suggested by the authors (e.g., Evangelista, 
2017; Pereira, 2017; Queirós, 2017). Several studies have also revealed the high levels of internal consistency of the Scale, ranging from 0,70 to 0,90 (e.g., Evangelista, 2017; Pereira, 2017; Queirós, 2017) - these results reinforce the instrument's use in investigations aimed to assess the level of satisfaction with the Occupational, Family and Leisure life roles.

\section{Procedure}

Once defined the psychological instruments to be used and the samples to apply them (adult workers), data collection was made through an online formulary, designed for the specific effects of each of the organizations. To do so, we resorted both directly to organizations, and to social media, and in specific cases data collection was made personally, in paper-and-pencil format. Prior to the presentation and application of the instruments, Informed Consent was always presented to the individuals, explaining the studies' framework and objectives, ensuring privacy and confidentiality rights over the gathered data.

\section{Results}

There is a tendency to give more importance to the Worker role (Table 1), an expected result once the samples analysed consist of adult workers, and the occupational activities are still the ones in which individuals spend more time and energy. Exceptions are Samples 4 and 8 (Participation Scale), and 4 and 5 (Commitment Scale), in which, respectively, the Homemaker, Leisure and Study roles, and Leisure and Study roles stood out. These results may be related to the samples' specificity (returnees, student workers, and emigrants), and tend to corroborate studies conducted in Portugal using the SI. These led to the conclusion that the importance given to certain roles varies depending on the professional group in which individuals take part (Duarte, 1993). There is also the salience of Leisure activities among the first three ordinances, except for the Commitment Scale in Sample 6, which was conducted with workers from a higher education institution. In this specific case, individuals attributed an emotional importance to the Study role, beyond the Worker and Homemaker roles. The results suggest, thus, some changes to the hierarchy of role importance when compared to the results obtained in the WIS (Ferreira Marques \& Miranda, 1995; Sverko \& Super, 1995) - the tendency for individuals to consider other important life roles beyond the Worker and Homemaker ones, which is an indicator of the importance given to other activities performed outside these two contexts, and a contribution to the overall level of satisfaction and well-being of individuals.

Regarding the satisfaction with life roles, despite the strong salience of the Worker role, individuals do not reveal to be more satisfied with their occupational activity. On the contrary, the levels of satisfaction with the Family and Leisure activities are higher. That is, the greater salience of the Worker role does not necessarily mean that individuals feel satisfied with their occupational activities. Exception for Sample 8, where a direct relationship between salience of study and occupational satisfaction has been confirmed - in other words, occupational satisfaction increases with the importance attached to the study role. It should be noted again the specificity of the context, which in this case included a sample of student-working adults. In general, these individuals did not have a family nucleus, being Work and Study the core activities of their lives. 
Regarding the study of correlations between role salience and satisfaction with life roles, there is a tendency to reveal that the salience of a role is related to the satisfaction obtained with that same role, corroborating the relation between involvement in a role and satisfaction in the performance of its activities (Carlson \& Kakmar, 2000). So, correlations were found between satisfaction and salience (in both Participation and Commitment Scales), in what concerns Worker role, Family/ Homemaker role and Leisure activities. Also, there is no relation between the salience of a role and the satisfaction obtained with the performance in other roles. Although there seems to be a few exceptions, namely, relations between the salience of Citizen and Leisure roles and satisfaction with Family, and the salience of the Study and Citizen roles and satisfaction with the roles that, according to theory, are more linked - respectively, Work Satisfaction and Satisfaction with Leisure activities. These latest results, also inseparable from the specificity of the samples under study, and from the organizational contexts in question, reinforce the possibility of individuals to obtain a higher level of satisfaction and well-being by dedicating their free time (Leisure role) to community services (Citizen role), both roles that tend to have a psychological association with each other (Lima et al., 2014).

\section{Table 1}

Summary of the results obtained in the eight samples: first three ordinances of SI (Participation Scale [PS] and Commitment Scale [CS]), and SLRS.

\begin{tabular}{|c|c|c|c|c|c|c|c|c|c|c|c|}
\hline \multirow[t]{2}{*}{$\begin{array}{l}\text { Samples/ } \\
\text { Ordinances }\end{array}$} & \multicolumn{4}{|c|}{$\begin{array}{c}\mathbf{1}^{\text {* }} \\
(\mathrm{n}=116)\end{array}$} & \multirow{2}{*}{$\begin{array}{c}2 \\
(\mathrm{n}= \\
86)\end{array}$} & \multirow{2}{*}{$\begin{array}{c}3 \\
(\mathrm{n}= \\
84) \\
W\end{array}$} & \multirow{2}{*}{$\begin{array}{c}4 \\
(\mathrm{n}= \\
102)\end{array}$} & \multirow{2}{*}{$\begin{array}{c}\mathbf{5} \\
(\mathrm{n}= \\
106) \\
\mathrm{W}\end{array}$} & \multirow{2}{*}{$\begin{array}{c}6 \\
(\mathrm{n}= \\
60) \\
W\end{array}$} & \multirow{2}{*}{$\begin{array}{c}7 \\
(n= \\
61) \\
W\end{array}$} & \multirow{2}{*}{$\begin{array}{c}8 \\
(\mathrm{n}= \\
90) \\
\mathrm{S}\end{array}$} \\
\hline & $1^{\text {st }}$ & W & W & W & & & & & & & \\
\hline \multirow{3}{*}{$\begin{array}{l}\text { PS } \\
\text { (SI) }\end{array}$} & $2^{\text {nd }}$ & $\mathrm{H}$ & $\mathrm{H}$ & $L$ & $\mathrm{~L}$ & $\mathrm{~L}$ & $\mathrm{~L}$ & $S$ & $S$ & $\mathrm{~L}$ & W \\
\hline & $3^{\text {rd }}$ & L & $\mathrm{L}$ & $S$ & $\mathrm{H}$ & $S$ & W & L & L & $\mathrm{H}$ & $\mathrm{L}$ \\
\hline & $1^{\text {st }}$ & W & W & W & $w$ & W & $\mathrm{L}$ & $S$ & W & $w$ & W \\
\hline \multirow[t]{3}{*}{ CS (SI) } & $2^{\text {nd }}$ & $\mathrm{H}$ & $\mathrm{H}$ & $L$ & $L$ & $L$ & $\mathrm{H}$ & $\mathrm{L}$ & $S$ & $L$ & $S$ \\
\hline & $3^{\text {rd }}$ & $\mathrm{L}$ & L & $S$ & $\mathrm{H}$ & $S$ & W & w & $\mathrm{H}$ & $\mathrm{H}$ & $\mathrm{L}$ \\
\hline & $1^{\text {st }}$ & $F$ & $\mathrm{~F}$ & $\mathrm{~L}$ & L \& & $F$ & $\mathrm{~F}$ & $F$ & $\mathrm{~F}$ & $\mathrm{~F}$ & W \\
\hline \multirow[t]{2}{*}{ SLRS } & $2^{\text {nd }}$ & $\mathrm{L}$ & L & $\mathrm{F}$ & $\mathrm{F}$ & $\mathrm{L}$ & L & w & $\mathrm{L}$ & $\mathrm{L}$ & $F$ \& \\
\hline & $3^{\text {rd }}$ & W & W & $w$ & W & w & w & $L$ & w & w & $\mathrm{L}$ \\
\hline
\end{tabular}

Note. PS: Participation Scale; CS: Commitment Scale; SI: Salience Inventory; SLRS: Satisfaction with Life Roles Scale; W: Work; H: Homemaker; L: Leisure; F: Family; S: Study.

* In the 1st sample, results are presented in function of the study's sub-samples, corresponding, respectively, to the Baby Boom, $\mathrm{X}$ and Y Generations.

\section{Discussion}

Based on the results obtained, it is thus possible to affirm the tendency revealed in the study on counselling and career management about role salience with a sample of adult workers (Lima et al., 2014) - in which individuals give increasingly more importance to the roles other than those in which they generally tend to spend more of their time and energy with: Worker and Family. Given 
the diversity of samples covered in this study, the importance of the results is not inseparable from their specificity and, consequently, from the organizational contexts in which the individuals are inserted.

Although the Worker role is the one that stands out the most in the samples under analysis, besides the leisure activities, individuals do not reveal to be more satisfied with their professional activity, but rather with the Family and Leisure roles. Thus, it can be said that the level of satisfaction and well-being of individuals increasingly depends on the balance between the performance of different life roles. While the Worker role continues to be central to most of the individuals throughout life, life is not just about work. It is becoming increasingly important to conciliate the time and energy spent in other activities that contribute to life quality, well-being, and satisfaction with life in general.

It is therefore important to contribute to the conciliation of the individuals' different activities, and to develop feelings of well-being and satisfaction, to increase workers' commitment to the individual-organization binomial. That is, to contemplate the existence of other life roles that make each human being unique, contributing to the workers' singularity, and to their personal development and identity in an organizational context. On the other hand, satisfied workers are motivated workers, and motivation will always be a path to greater effectiveness and productivity.

Since work is inseparable from personal life, the management of various life roles has become increasingly prominent (Hirschi, 2020) for both individuals and organizations. As a result, there must be an effort by companies to understand the particularities of their employees, attaching importance not only to their satisfaction in the workplace, but also in the other life scenarios. The articulation between Worker, Family and Leisure life roles provides the desired balance for the definition and implementation of the individual's lifestyle and, consequently, for his/ her well-being in each of the different stages he/ she is obliged and/ or motivated to perform throughout his/ her life, particularly at work.

Therefore, it is important to help individuals "realize how to interpret and represent the tasks that each role and context places to them, which meaning they attach to them and how to integrate these representations in their story and personal build-up in career development and management" (Lima et al., 2014, p. 16). Despite of the strong salience of one life role, individuals may not reveal to be more satisfied with their activity in this life role and can experience conflict situations. These can lead to lower levels of satisfaction and well-being, which means a lack of work-life-balance. Interventions in counselling and career management can be especially important to help individuals overcome conflict between life roles, namely through the exploration of both positive and less positive aspects in each role played. Thus, career counsellors can be very helpful using the analysis of the roles' salience and identifying the ones that most affect the individuals' satisfaction with life, life roles and well-being.

In recent years, organizations have promoted the balance between work and personal life and have implemented organizational practices related to this same balance. The concept of "familyfriendly organizations" (Wood \& Menezes, 2010) stands out, as well as the family-friendly practices (e.g., Vyas et al., 2017; Doran et al., 2019; Feeney \& Stritch, 2019), arising from the concomitant performance of Work and Family roles in an organizational context. Considering the importance equally attached to other activities, translated in the present study by the Leisure role and the satisfaction level obtained with the Leisure activities, another highlight is for the implementation of other types of practices. As leisure activities are increasingly important in individuals' lives (Lima et al., 2014), flexible benefit programs allowing for a better balance between Work and Leisure roles can make an important contribution to the work life quality and to the workers' well-being. Thus, it suggests the creation and implementation of practices and policies that provide employees with the necessary support to manage the performance in multiple life roles, so that is the performance of Human Resources the major contribution to the development of their own organization. That is, these efforts would not only enhance the well-being of employees, but also contribute to the value, effectiveness, and productivity of organizations. 
Organizations have also promoted an evolution of the balance between professional life and personal life toward an integration of these two domains, because the generations in the current labour market demanded so (Ciarniene \& Vienazindiene, 2018; Sanchez-Hernandez et al., 2019). It is necessary to consider the differences between these, as each of these generations express different values and needs in the same challenging and mutable world. An up-to-date example of adjustment and adaptation situation is what everyone is facing nowadays because of the pandemic situation. This required many to work from home, and to be instantly able to lead with the different life roles in a very different way. On the other hand, the increasingly frequent use of remote work is going to change the labour market as well the ability of performing, developing, and balancing the work and non-work roles (Felstead \& Henseke, 2017). New demands and challenges are on the agenda regarding the importance of individuals' lives and well-being and, consequently, what concerns work-life balance. So, it is becoming more and more important to pay attention to the present issue and to adopt organizational practices that support the balance between the different spheres of individuals' lives. Noteworthy are the interventions in counselling and career management and a more personalized treatment in all the human resources interventions in organizational context, especially given the increasingly frequent use of remote work.

\section{References}

Allen, T. D., Herst, D. E., Bruck, C. S. \& Sutton, M. (2000). Consequences associated with work-tofamily conflict: A review and agenda for future research. Journal of occupational health psychology, 5(2), 278. https://doi.org/10.1037//1076-8998.5.2.278

Bloom, J., Rantanen, J., Tement, S. \& Kinnunen, U. (2018). Longitudinal leisure activity profiles and their associations with recovery experiences and job performance. Leisure Sciences, 40(3), 151. https://doi.org/10.1080/01490400.2017.1356254

Carlson, D. S. \& Kacmar, K. (2000). Work-family conflict in the organization: Do life role values make a difference? Journal of Management, 26(5), 1031-1054. https://doi.org/10.1177/014920630002600502

Ciarniene, R. \& Vienazindiene, M. (2018). Flexible work arrangements from generation and gender perspectives: Evidence from Lithuania. Engineering Economics, 29(1), 84-92. https://doi.org/10.5755/j01.ee.29.1.19247

Cook, E. P. (1994). Role salience and multiple roles: A gender perspective. The Career Development Quarterly, 43, 85-95. https:// https://doi.org/10.1002/j.2161-0045.1994.tb00849.x

Creighton-Smith, B., Cook, M. \& Edginton, C. (2017). Leisure, ethics, and spirituality. Annals of Leisure Research, 20(5), 546-562. https://doi.org/10.1080/11745398.2017.1295873

Dias, F. A. C. (2018). Saliência dos papéis, satisfação com os papéis de vida e intenção de turnover: Estudo com uma amostra de repatriados (Master's dissertation, Faculty of Psychology of the University of Lisbon). http://hdl.handle.net/10451/37566

Diener, E. (1984). Subjective well-being. Psychological Bulletin, 95, 542-575. https:// https://doi.org/10.1037/0033-2909.95 
Doran, E. L., Bartel, A. P. \& Waldfogel, J. (2019). Gender in the labor market: The role of equal opportunity and family-friendly policies. RSF: The Russell Sage Foundation Journal of the Social Sciences, 5(5), 168-197. https://doi.org/10.7758/RSF.2019.5.5.09

Duarte, M. E. (1993). Preocupações de carreira, valores e saliência das actividades em adultos empregados (Doctoral dissertation, Faculty of Psychology of the University of Lisbon). http://hdl.handle.net/10451/42398

Dumazedier, J. (2000). Lazer e Cultura Popular (3a ed.). Perspectiva.

Evangelista, A. R. C. (2017). Saliência dos papéis, satisfação com os papéis de vida e conflito trabalho-família: Estudo com uma amostra da área da restauração (Master's dissertation, Faculty of Psychology of the University of Lisbon). http://hdl.handle.net/10451/33171

Feeney, M. K. \& Stritch, J. M. (2019). Family-friendly policies, gender, and work-life balance in the public sector. Review of Public Personnel Administration, 39(3), 422-448. https://doi.org/10.1177/0734371X17733789

Felstead, A. \& Henseke, G. (2017). Assessing the growth of remote working and its consequences for effort, well-being and work-life balance. New Technology, Work \& Employment, 32(3), 195212. https://doi.org/10.1111/ntwe.12097

Ferreira-Marques, J. \& Miranda, M. J. (1995). Developing the Work Importance Study. In D. E. Super \& B. Šverko (Eds.) Life roles, values, and careers: International findings of the Work Importance Study (pp. 62-74). Jossey-Bass Inc. Publishers.

França, C., Silva, F. Q. B. \& Sharp, H. (2020). Motivation and satisfaction of software engineers. IEEE Transactions on Software Engineering, Software Engineering, 46(2), 118-140. https://doi.org/10.1109/TSE.2018.2842201

Hamid, F. A. (2012). Práticas de conciliação trabalho/ família em organizações de excelência (Master's dissertation, Faculty of Economy of the University of Coimbra). http://hdl.handle.net/10316/21555

Harpaz, I. \& Fu, X. (2002). The structure of the meaning of work: A relative stability amidst change. Human Relations, 55, 639-668. https://doi.org/10.1177/0018726702556002

Hirschi, A. (2020). Whole-life career management: A counseling intervention framework. Career Development Quarterly, 68(1), 2-17. https://doi.org/10.1002/cdq.12209

Hoboubi, N., Choobineh, A., Ghanavati, F., Keshavarzi, S. \& Hosseini, A. (2017). The impact of job stress and job satisfaction on workforce productivity in an Iranian petrochemical industry. Safety and Health at Work, 8(1), 67-71. https://doi.org/10.1016/i.shaw.2016.07.002

Janeiro, I. \& Lima, M. R. (2013). Escala de Satisfação com os Papéis de Vida (ESPV): Versão experimental. Portugal.

Jian, G. \& Dalisay, F. (2018). Talk matters at work: The effects of leader-member conversational quality and communication frequency on work role stressors. International Journal of Business Communication, 55(4), 483-500. https://doi.org/10.1177/2329488415594157

Kalliath, T. \& Brough, P. (2008). Work-life balance: A review of the meaning of the balance construct. Journal of Management and Organization, 14(3), 323-327. https://doi.org/10.5172/jmo.837.14.3.323

Kidd, J. M. \& Knasel, E. (1979). Work values and work salience: A review of research. Paper presented at "The $2^{\text {nd }}$ Work Importance Study Conference". United Kingdom. 
Kuykendall, L., Lei, X., Tay, L., Cheung, H. K., Kolze, M., Lindsey, A., Silvers, M. \& Engelsted, L. (2017). Subjective quality of leisure \& worker well-being: Validating measures \& testing theory. Journal of Vocational Behavior, 103, 14-40. https://doi.org/10.1016/j.jvb.2017.07.007

Lassance, M. C. \& Sarriera, J. C. (2009). Carreira e saliência dos papéis: Integrando o desenvolvimento pessoal e profissional. Revista Brasileira de Orientação Profissional, 10(2), 15-31.

Lima, M. R. (1998). Orientação e desenvolvimento da carreira em estudantes universitários: Estudo das atitudes de planeamento e exploração, identidade vocacional, saliência dos papéis e factores de carreira (Doctoral dissertation, Faculty of Psychology of the University of Lisbon). http://hdl.handle.net/10451/42370

Lima, M. R. \& Janeiro, I. (2012). Escala de satisfação com os papéis de vida: Estudo com uma amostra de trabalhadores do sector farmacêutico. Paper presented at "VII Simpósio sobre Comportamento Organizacional". Lisbon, Portugal.

Lima, M. R., Beirão da Cruz, R. \& Rafael, M. (2014). La relevancia de los roles vitales para el bienestar de los individuos. Revista Española de Orientación y Psicopedagogía, 25(3), 8-19. https://doi.org/10.5944/reop.vol.25.num.3.2014.13855

Locke, E. A. (1976). The nature and causes of job satisfaction. In M. D. Dunette (Ed.). Handbook of Industrial and Organizational Psychology. Rand McNally.

Navarro, M., D'Agostino, A. \& Neri, L. (2020). The effect of urbanization on subjective well-being: Explaining cross-regional differences. Socio-Economic Planning Sciences, 100824. https://doi.org/10.1016/..seps.2020.100824

Nevill, D. D. \& Super, D. E. (1986). The Salience Inventory: Theory, application, and research: Manual. Consulting Psychologists Press.

Nunes, M. \& Hutz, C. (2014). Análise da produção de artigos científicos sobre o lazer: Uma revisão. Psicologia: Teorias e Pesquisa, 30(3), 307-315.

Olson, D. H. (2000). Circumplex model of marital and family systems. Journal of Family Therapy, 22(2), 144-167. https://doi.org/10.1111/1467-6427.00144

Ortuño, V. E. C., Janeiro, I. \& Lima, R. (2016). Análisis factorial confirmatorio del inventario de satisfacción con los roles de vida. Paper presented at "2.․ Congreso Latinoamericano para el Avance de la Ciencia Psicológica". Buenos Aires, Argentina.

Pavot, W. \& Diener, E. (2008). The satisfaction with life scale and the emerging construct of life satisfaction? Journal of Positive Psychology, 3(2), 137-152. https:// https://doi.org/10.1080/17439760701756946

Pereira, S. A. R. (2017). Saliência dos papéis e satisfação com os papéis de vida: A influência da perceção do apoio organizacional numa amostra de trabalhadores-estudantes (Master's dissertation, Faculty of Psychology of the University of Lisbon). https://repositorio.ul.pt/bitstream/10451/33361/1/ulfpie052876 tm tese.pdf

Petzold, M. (1996). The psychological definition of "the family". In M. Cusinato (Org.), Research on family: Resources and needs across the world (pp. 25-44). LED-Edicioni Universitarie.

Pöllänen, S. \& Voutilainen, L. (2018). Crafting well-being: Meanings and intentions of stay-at-home mothers' craft-based leisure activity. Leisure Sciences, 40(6), 617-633. https://doi.org/10.1080/01490400.2017.1325801 
Queirós, J. M. G. A. (2017). Relação entre saliência dos papéis e satisfação com os papéis de vida: Estudo com uma amostra de adultos trabalhadores emigrantes (Master's dissertation, Faculty of Psychology of the University of Lisbon). http://hdl.handle.net/10451/33563

Sanchez-Hernandez, M. I., Gonzalez-Lopez, O. R., Buenadicha-Mateos, M. \& Tato-Jimenez, J. L. (2019). Work-life balance in great companies and pending issues for engaging new generations at work. International Journal of Environmental Research and Public Health, 16(24). https://doi.org/10.3390/ijerph16245122

Schnettler, B., Miranda-Zapata, E., Grunert, K. G., Lobos, G., Denegri, M., Hueche, C. \& Poblete, $H$. (2018). University student profiles according to satisfaction with life, food and family / Perfiles de estudiantes universitarios según la satisfacción con la vida, la alimentación y la familia. Revista Chilena de Nutrición, 45(3), 263-270. https://doi.org/10.4067/s0717$\underline{75182018000400263}$

Stoilkovska, B. B., Šurbanovska, O., Fritzhand, A. \& Ivanova, T. S. (2017). Life role salience and subjective well-being among macedonian employees: Does family-supportive organization perception moderate this relationship. International Journal of Occupational Medicine and Environmental Health, 31(3), 281-291. https://doi.org/10.13075/ijomeh.1896.01204

Stryker, S. \& Serpe, R. T. (1994). Identity salience and psychological centrality: Equivalent, over lapping, or complementary concepts? Social Psychology Quarterly, 57, 16-35. https:// https://doi.org/10.2307/2786972

Stubbe, J. H., Posthuma, D., Boomsma, D. I. \& de Geus, E. J. C. (2005). Heritability of life satisfaction in adults: a twin-family study. Psychological Medicine, 35(11), 1581-1588. https://doi.org/10.1017/S0033291705005374

Super, D. E. (1980). A life span, life-space approach to career development. Journal of Vocational Behavior, 16, 282-289. https://doi.org/10.1016/0001-8791(80)90056-1

Super, D. E. (1990). A life span, life-space approach to career development. In D. Brown \& L. Brooks (Eds.), Career choice and development (2nd ed.). Jossey-Bass.

Sverko, B. \& Super, D. E. (1995). The findings of the Work Importance Study. In D.E. Super \& Sverko (Eds.), Life roles, values, and careers: International findings of the Work Importance Study (pp.349-358). Jossey-Bass.

Sverko, B., Babarovic, T. \& Sverko, I. (2008). Assessment of values and role salience. In J. A. Athanasou \& R. V. Esbroeck (Eds.), International Handbook of Career Guidance (pp. 539564). Springer.

Vyas, L., Lee, S. Y. \& Chou, K.-L. (2017). Utilization of family-friendly policies in Hong Kong. International Journal of Human Resource Management, 28(20), 2893-2915. https://doi.org/10.1080/09585192.2016.1138498

Wang, W., Wang, Y., Zhang, Y. \& Ma, J. (2020). Spillover of workplace IT satisfaction onto job satisfaction: The roles of job fit and professional fit. International Journal of Information Management, 50, 341-352. https://doi.org/10.1016/j.ijinfomgt.2019.08.011

Wood, S. \& Menezes, L. (2010). Family-friendly management, organizational performance, and social legitimacy. The International Journal of Human Resource Management, 21(10), 1575-1597. https://doi.org/10.1080/09585192.2010.500484 
Fecha de entrada: 11 noviembre 2019 Fecha de revisión: 16 mayo 2020 Fecha de aceptación: 22 junio 2020 